\title{
Haemorrheological response to plasma exchange in Raynaud's syndrome
}

\author{
A J DODDS, M J G O'REILly, C J P YATES, L T COTTON, P T FLUTE, J A DORMANDY
}

British Medical fournal, 1979, 2, 1186-1187

HAEMORRHEOLOGICAL AND HAEMODYNAMIC MEASUREMENTS

\section{Summary and conclusions}

Eight patients with Raynaud's syndrome were treated by weekly plasma exchange for four weeks using a Haemonetics Model 30 Blood Processor. The mean whole-blood viscosity at a shear rate of $0.77 / \mathrm{s}$ was significantly lower after treatment, and the mean index of red-cell deformability was significantly improved. In four patients studied serially the mean percentage fall in whole-blood viscosity after a single plasma exchange was $49 \%$ at $0.77 / \mathrm{s}$ but only $14 \%$ at $91 / \mathrm{s}$. All patients noticed symptomatic improvement including healing of ischaemic digital ulcers. In six patients the number of digital arterial segments containing detectable blood flow was measured by directional Doppler; in all six the number increased.

It is concluded that plasma exchange is an effective means of haemorrheological treatment and may be beneficial in patients with digital ischaemia.

\section{Introduction}

The physical properties of blood are increasingly being recognised as being important in causing abnormalities of blood flow. ${ }^{1}$ Changes in these properties have been described in Raynaud's syndrome and may contribute to the episodic ischaemia found in patients with this disease. ${ }^{2}$ Plasma exchange can substantially reduce the concentration of plasma fibrinogen as well as other plasma proteins. ${ }^{4}$ It may thus lower viscosity and improve the flow properties of blood. As part of a trial of plasma exchange in Raynaud's syndrome ${ }^{5}$ we studied haemorrheological variables in detail before and after plasma exchange in eight patients and related our findings to clinical results. We sought objective evidence of improvement in six of the patients by investigating the presence of blood flow in patent digital arterial segments with a Doppler ultrasound probe.

\section{Patients and methods}

We studied eight patients with Raynaud's syndrome unrelated to trauma, vibration, or a proximal vascular lesion. In four the primary disease was scleroderma, and in four the syndrome was idiopathic. No cryoproteins, paraproteins, or cold agglutinins were detected in any of the cases.

St George's Hospital Medical School, London SW17 ORE

A J DODDS, FRACP, research fellow

$P$ T FLUTE, MD, FRCPATH, professor of haematology

King's College Hospital Medical School, London SE5

M J G O'REILLY, FRCS, honorary senior registrar

L T COTTON, MCH, FRCS, director of biomedical engineering

St James's Hospital, London SW12

C J P YATES, FRCS, honorary senior registrar

J A DORMANDY, FRCS, consultant surgeon

Apparent whole-blood viscosity at $37^{\circ} \mathrm{C}$ was measured at two shear rates $(0.77 / \mathrm{s}$ and $91 / \mathrm{s})$ using a Contraves Low Shear 2 Rheometer. The results were adjusted to a packed cell volume (PCV) of $45 \%$. Plasma viscosity at $37^{\circ} \mathrm{C}$, plasma fibrinogen concentration, ${ }^{7}$ and PCV were also measured, the latter by microhaematocrit.

Red-cell deformability was assessed by a filtration technique. Whole blood was collected into solid lithium heparin and centrifuged at $3000 \mathrm{rpm}$ for 15 minutes. The plasma was aspirated and prefiltered through a type RA Millipore filter (Millipore (UK), London) of $1.2 \mu \mathrm{m}$ pore size to remove platelets and protein precipitates. A sample of the packed cells $(0.2 \mathrm{ml})$ was resuspended in $5 \mathrm{ml}$ of autologous prefiltered plasma to produce a $5 \%$ suspension. Aliquots $(1 \mathrm{ml})$ of this suspension were filtered under hydrostatic pressure through individual $5 u \mathrm{~m}$ polycarbonate sieves (Nuclepore Corporation, California, USA). These were of $5 \mathrm{um}$ pore size and came from the same high-grade batch. Filtrations were performed in triplicate at constant temperature $\left(21 \pm S D 1^{\circ} \mathrm{C}\right)$. The volume of cells filtered in 60 seconds was compared with the volume contained in $1 \mathrm{ml}$ of the suspension by comparing the optical densities at $540 \mathrm{~mm}$ of a similar dilution of each in Drabkin's solution. The results were expressed as an index (deformability index = optical density of filtrate/optical density of suspension) ranging from 0 to 1 . A low result indicated fewer cells filtered. The coefficient of variation of individual filtrations on the same sample was $9 \cdot 2 \%$. A study of 20 normal subjects showed a mean deformahility index of 0.63 (SD 0.20 ) (unpublished observations).

The presence of digital artery pulses was assessed in six patients by using a directional Doppler velocimeter. Each finger was divided into proximal, middle, and distal thirds, each having a radial and ulnar digital segment. Thus the hand, including the thumb, possessed 28 digital segments for testing. Patency rates were performed at $15^{\circ} \mathrm{C}$ and $21^{\circ} \mathrm{C} .^{5}$

All investigations were carried out before treatment and six weeks after the last plasma exchange. In four of the patients the haemorrheological tests were performed weekly during the treatment.

\section{PLASMA EXCHANGE}

Each patient received a weekly plasma exchange for four weeks using a Haemonetics Model 30 Blood Processor (Haemonetics Corporation, Boston, USA). The mean volume exchanged per week was 1.91 , and the replacement solutions were 1.21 human plasma protein fraction, 0.51 of polygeline (Haemaccel), and 0.5-1.0 1 of physiological saline. Heparin (six cases) and acid-citrate-dextrose solution (two) was infused into the centrifuge bowl to prevent clotting.

\section{Results}

Whole-blood viscosity at $0 \cdot 77 / \mathrm{s}$ was significantly lower at follow-up even when corrected for changes in PCV (table I). Blood viscosity was also lower at $91 / \mathrm{s}$, but the significance was lost when the values

TABLE I-Mean $( \pm S D)$ haemorrheological values before and six weeks after four weekly plasma exchanges in eight patients

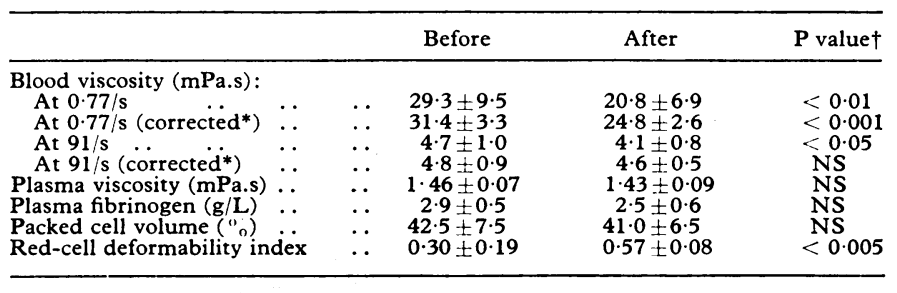

*Adjusted to a standard packed cell volume $\left(45^{\circ} \%\right)$.

$\dagger$ Paired Student's $t$ test.

SI to traditional units-Viscosity: $1 \mathrm{mPa} . \mathrm{s} \approx 1 \mathrm{cP}$. 
TABLE II-Mean ( $\pm S D$ ) serial haemorrheological values before, immediately after, and six weeks after four weekly plasma exchanges in four patients

\begin{tabular}{|c|c|c|c|c|c|c|c|c|c|c|c|}
\hline & & & \multicolumn{2}{|c|}{ First week } & \multicolumn{2}{|c|}{ Second week } & \multicolumn{2}{|c|}{ Third week } & \multicolumn{2}{|c|}{ Fourth week } & \multirow[b]{2}{*}{ Follow-up } \\
\hline & & & Before & After & Before & After & Before & After & Before & After & \\
\hline $\begin{array}{l}\text { Blood viscosity (mPa.s): } \\
\text { At } 0.777 / \mathrm{s} \quad \ldots \\
\text { At } 0.77 / \mathrm{s} \text { (corrected*) } \\
\text { At } 91 / \mathrm{s} \quad \ldots \\
\text { At } 91 / \mathrm{s} \text { (corrected*).. } \\
\text { Plasma viscosity (mPa.s) } \\
\text { Plasma fibrinogen }(\mathrm{g} / 1) \\
\text { Packed cell volume ("). } \\
\text { Red-cell deformability index }\end{array}$ & $\begin{array}{l}\cdots \\
\cdots \\
\cdots \\
\cdots \\
\cdots\end{array}$ & $\begin{array}{l}\cdots \\
\cdots \\
\cdots \\
\cdots \\
\cdots\end{array}$ & $\begin{array}{c}27 \cdot 0 \pm 5 \cdot 8 \\
30 \cdot 4 \pm 3.8 \\
3.9 \pm 0.4 \\
4 \cdot 4 \pm 0.4 \\
1 \cdot 49 \pm 0.05 \\
2 \cdot 8 \pm 0.3 \\
39.5 \pm 2.3 \\
0 \cdot 26 \pm 0.12\end{array}$ & $\begin{array}{c}10 \cdot 5 \pm 4 \cdot 6 \\
14 \cdot 3 \pm 4 \cdot 1 \\
3.5 \pm 0 \cdot 3 \\
4 \cdot 1 \pm 0 \cdot 2 \\
1 \cdot 27 \pm 0.08 \\
1 \cdot 5 \pm 0 \cdot 2 \\
38 \cdot 0 \pm 3 \cdot 5 \\
\end{array}$ & $\begin{array}{c}17.5 \pm 3.8 \\
24.5 \pm 3.9 \\
3.9 \pm 0.3 \\
4.6 \pm 0.2 \\
1.43 \pm 0.09 \\
2.6 \pm 0.3 \\
38.3 \pm 1.8 \\
0.48 \pm 0.04\end{array}$ & $\begin{array}{c}8 \cdot 1 \pm 3 \cdot 0 \\
11 \cdot 9 \pm 0 \cdot 8 \\
3 \cdot 1 \pm 0 \cdot 2 \\
3 \cdot 8 \pm 0 \cdot 1 \\
1 \cdot 22 \pm 0.04 \\
1 \cdot 2 \pm 0 \cdot 2 \\
35 \cdot 8 \pm 2 \cdot 3 \\
\end{array}$ & $\begin{aligned} 12.8 & \pm 3.5 \\
20 \cdot 1 & \pm 3.2 \\
3.6 & \pm 0.2 \\
4.3 & \pm 0.2 \\
1.32 & \pm 0.03 \\
2.5 & \pm 0.4 \\
37.3 & \pm 2.3 \\
0.54 & \pm 0.03\end{aligned}$ & $\begin{aligned} 7.7 & \pm 4 \cdot 1 \\
11.9 & \pm 2.7 \\
3 \cdot 0 & \pm 0.3 \\
3.7 & \pm 0.3 \\
1 \cdot 17 & \pm 0.03 \\
1.2 & \pm 0.3 \\
34.5 & \pm 2.3\end{aligned}$ & $\begin{array}{c}13.0 \pm 5.1 \\
19.8 \pm 2.7 \\
3.5 \pm 0.2 \\
4.4 \pm 0.1 \\
1.28 \pm 0.03 \\
2.5 \pm 0.3 \\
37.0 \pm 2.5 \\
0.56 \pm 0.06\end{array}$ & $\begin{aligned} 7.5 & \pm 4 \cdot 0 \\
12.5 & \pm 2 \cdot 7 \\
3.2 & \pm 0.3 \\
3.9 & \pm 0 \cdot 2 \\
1 \cdot 12 & \pm 0.03 \\
1.1 & \pm 0.1 \\
34.8 & \pm 3.3\end{aligned}$ & $\begin{aligned} 17.5 & \pm 6.2 \\
22.8 & \pm 5.9 \\
3.8 & \pm 0.6 \\
4.3 & \pm 0.6 \\
1.40 & \pm 0.18 \\
2.7 & \pm 0.6 \\
38.8 & \pm 1.9 \\
0.58 & \pm 0.05\end{aligned}$ \\
\hline
\end{tabular}

+ Red-cell deformability not measured immediately after plasma exchanges.

were corrected for PCV. Plasma viscosity, plasma fibrinogen concentration, and PCV were all lower but not significantly. The deformability index was initially well below the normal range $(P<0.01$, Student's $t$ test) but improved after plasma exchange.

Serial changes in four patients (table II) showed a mean fall of $49^{\circ}{ }_{0}$ in blood viscosity at $0.77 / \mathrm{s}$ immediately after each exchange but of only $14^{\circ}{ }_{0}^{\circ}$ at $91 / \mathrm{s}$. Plasma fibrinogen concentration also fell acutely by $52^{\circ}{ }^{\circ}$ and PCV by $5 \cdot 6^{\circ} \%$. Blood viscosity at low shear fell progressively over the period of treatment. Red-cell deformability, measured only before each exchange, improved after treatment, particularly in the first two weeks.

All six patients studied showed an increase in the number of digital artery segments containing detectable blood flow (fig). Overall there was a significant improvement at both $15^{\circ} \mathrm{C}(\mathrm{P}<0.02$; Wilcoxon's rank sum test $)$ and $21^{\circ} \mathrm{C}(\mathbf{P}<0.03$; Wilcoxon's rank sum test). At follow-up all the patients had improved clinically as evidenced by less pain and reduced frequency of attacks. Digital ulcers, initially present in three, had healed. These results have been confirmed in a controlled clinical trial."
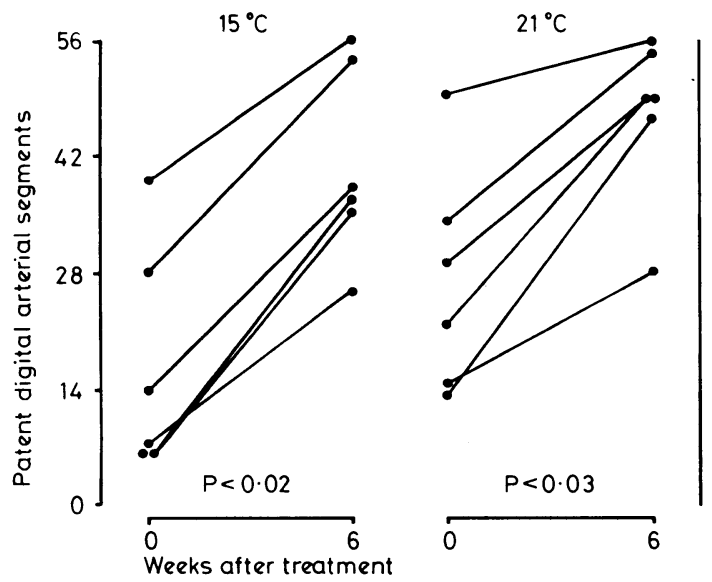

Digital artery patency rate before and six weeks after four weekly plasma exchanges in six patients at $15^{\circ} \mathrm{C}$ and $21^{\circ} \mathrm{C}$.

\section{Discussion}

The physical flow properties of blood are particularly important in conditions in which the composition of the blood as well as the vessels themselves may be abnormal. ${ }^{1}$ Blood hyperviscosity is well documented in Raynaud's syndrome, ${ }^{2}{ }^{3}$ though not in primary Raynaud's disease. ${ }^{8}$ The low temperatures in the digits may accentuate this raised viscosity. ${ }^{2}$ As several studies have shown an improvement in blood flow when viscosity is lowered, ${ }^{910}$ we thought it appropriate to investigate this approach to treatment.

Plasma exchange is an effective means of reducing blood viscosity in macroglobulinaemia. ${ }^{11}$ In this study we have shown that it may also be effective in patients with Raynaud's syndrome. The acute effect is largely brought about by a reduction in plasma fibrinogen concentration, and thus the major change is seen at low shear rates. This may be particularly relevant to patients with Raynaud's syndrome, in whom digital blood flow is reduced.1213 The sustained reduction in blood viscosity is more difficult to explain, as the plasma fibrinogen concentration was not significantly lower at follow-up. The present study suggests that the improvement in red-cell deformability may be a factor.

The finding of reduced red-cell deformability in patients with Raynaud's syndrome has been predicted on theoretical grounds." Deformability is an important property of red cells that permits blood flow under various conditions. It may be particularly important in determining flow in the microcirculation. ${ }^{14}$ As red-cell deformability is reduced by acidosis, ${ }^{15}$ the local ischaemia in Raynaud's syndrome may amplify the reduction detected in this study. The improvement in red-cell deformability after plasma exchange would suggest the removal of an abnormal plasma factor interfering with red-cell behaviour. ${ }^{14}$

Objective evidence of improvement was supplied by the increase in digital patency rates. The close relation to haemorrheological improvement would support Schmid-Schönbein's hypothesis that rheological obstruction is important in abnormal peripheral circulation. ${ }^{1}$

We acknowledge the support of Berk Pharmaceuticals.

Requests for reprints should be addressed to: $\mathrm{Mr}$ J A Dormandy, St James's Hospital, London SW12 8HW.

\section{References}

${ }^{1}$ Schmid-Schönbein, H, Acta Chirurgica Scandinavica, 1976, suppl No 465, p 10.

2 Dintenfass, L, Angiology, 1977, 28, 472.

3 Goyle, K B, and Dormandy, J A, Lancet, 1976, 1, 1317.

4 Lockwood, C M, et al, Lancet, 1976, 1, 711.

5 O'Reilly, M J G, et al, British Medical fournal, 1979, 1, 1113.

${ }^{6}$ Dormandy, J A, Biomedical Engineering, 1974, 9, 284.

7 Ingram, G I C, Biochemical fournal, 1952, 51, 583.

${ }^{8}$ McGrath, M A, Peek, R, and Penny, R, Australian and New Zealand Fournal of Medicine, 1978, 8, 126.

${ }^{9}$ Dormandy, J A, British Medical fournal, 1971, 4, 716.

10 Thomas, D J, et al, Lancet, 1977, 2, 941.

11 Solomon, A, and Fahey, J L, Annals of Internal Medicine, 1963, 56, 789.

12 McGrath, M A, Peek, R, and Penny, R, Annals of the Rheumatic Diseases, 1977, 36, 569 .

${ }^{13}$ Coffman, J D, and Cohen, A S, New England fournal of Medicine, 1971, 285, 259.

${ }^{14}$ Braasch, D, British Fournal of Haematology, 1974, 24, 405.

${ }^{15}$ Lancet, 1978, 2, 1348.

(Accepted 24 August 1979) 